JPdK Volume 3 Nomor 1 Tahun 2021 Halaman 21-27

JURNAL PENDIDIKAN dan KONSELING

Research \& Learning in Faculty of Education

\title{
Pengaruh Model Pembelajaran Cycle Learning 5E Terhadap Keterampilan Sains Peserta Didik Sekolah Dasar
}

\author{
Ranita $^{1}$, Amir Luthfi ${ }^{2}$, Iis Aprinawati ${ }^{3}$ \\ Program Studi Pendidikan Guru Sekolah Dasar \\ Fakultas Ilmu Pendidikan \\ Universitas Pahlawan Tuanku Tambusai \\ Email: Ranitarani919@gmail.com
}

\begin{abstract}
Abstrak
Penelitian ini dilaksanakan di SDN 005 Langgini Bangkinang pada bulan September 2020. Populasi dari penelitian ini adalah seluruh siswa kelas IV SDN 005 Bangkinang sedangkan sampelnya adalah siswa kelas IVB dan siswa kelas IVC. Metode yang digunakan dalam penelitian ini adalah quasi eksperiment dengan desain penelitian Pretest Posttest Desain. Desain ini terdapat dua kelompok yang dipilih secara random, kemudian kelompok eksperimen diberikan perlakuan pembelajaran IPA dengan model pembelajaran Cycle Learning 5E, sedangkan kelompok kontrol dengan model pembelajaran POE. Instrumen yang digunakan dalam penelitian berupa soal tes keterampilan proses sains dan lembar observasi keterampilan proses sains. Hasil penelitian yang diperoleh dan hasil pengujian statistik yang telah dilakukan diperoleh skor rata-rata posttest kelas eksperimen 81,25 lebih tinggi dari skor rata-rata posttest pada kelas kontrol 74,4. Hal ini dibuktikan dengan hasil uji statistik menunjukkan bahwa thitung 2,877 > ttabel 1,714 untuk taraf signifikan 5\% atau $\alpha=0,05$ sehingga diterima dan 0 ditolak. Berdasarkan hasil penelitian tersebut maka dapat disimpulkan bahwa penerapan model pembelajaran Cycle Learning $5 E$ berpengaruh terhadap keterampilan proses sains siswa.
\end{abstract}

Kata Kunci: Cycle Learning 5E, Keterampilan Proses Sains.

\begin{abstract}
Abstrak
This research was conducted at SDN 005 Langgini Bangkinang in September 2020. The population of this study were all fourth grade students of SDN 005 Bangkinang while the samples were students of class IVB and class IVC students. The method used in this study is a quasi-experimental research design. Pretest Posttest Design. This design, there are two groups selected randomly, then the experimental group is given the science learning treatment with the Cycle Learning 5E model, while the control group uses the POE learning model. The instruments used in the research were questions of science process skills tests and observation sheets of science process skills. The results of the research obtained and the results of statistical testing that have been carried out, it is obtained that the posttest average score of the experimental class is 81,25 higher than the average posttest score in the control class 74,4. This is evidenced by the results of statistical tests showing that $t$ count $2.877>t$ table 1.714 for a significant level of $5 \%$ or $\alpha=0.05$ so that is accepted and 0 is rejected. Based on these results, it can be concluded that the application of the Cycle Learning 5E model has an effect on students' science process skills
\end{abstract}

Key words: Cycle Learning 5E, Science Process Skill.

\section{PENDAHULUAN}

Perkembangan ilmu dan teknologi serta perkembangan sosial budaya yang pesat memberikan tantangan tersendiri bagi guru dan peserta didik dalam meningkatkan prestasi belajar. Setiap peserta didik senantiasa ditantang untuk terus meningkatkan kegiatan belajarnya melalui berbagai sumber dan 
media seperti internet, televisi, perangkat audio visual, selain belajar langsung dari guru, sedangkan guru ditantang untuk bisa mendorong, membimbing dan memberi fasilitas belajar kepada peserta didik.

Dalam rangka mewujudkan tujuan pendidikan nasional yang tercantum dalam Undang-Undang RI No. 20 Tahun 2003, diperlukan suatu pedoman dalam penyelengaraan pendidikan atau yang disebut Kurikikulum. Undang-undang Sisdiknas No. 20 Tahun 2003 menjelaskan bahwa kurikulum adalah seperangkat rencana dan pengaturan mengenai tujuan, isi dan bahan pelajaran serta cara yang digunakan sebagai pedoman penyelenggaraan kegiatan pembelajaran untuk mencapai tujuan pendidikan.

Perubahan kurikulum 2013 ini menekankan pendekatan ilmiah atau pembelajaran yang berpusat kepada peserta didik. Dengan tujuan untuk mendorong siswa agar lebih aktif, kreatif, inovati dan mandiri. Untuk dapat menyelenggarakan pendidikan sesuai tujuan pendidikan nasional, salah satu sub sistemnya adalah guru, seorang guru adalah pelaksana utama pendidikan. Sebagai pendidik wajib menyampaikan pengetahuannya kepada siswa dengan cara adil dalam berbagai hal terhadap peserta didik. Hasildan mutu pendidikan tergantung pada kualitas dan kinerja yang diperlihatkan oleh seorang guru. Dengan Keadaan sekolah dengan sistem guru kelas tidak menutup kemungkinan banyakguru yang mengalami kesulitan dalam menggunakan model yang tepat untuk mencapai tujuan pembelajaran yang optimal, karena guru dituntut untuk mengejar target materi yang cukup banyak dan harus diselesaikan pada setiap semester. Keberhasilan pengajaran tergantung pada keberhasilan siswa dalam proses belajar mengajar Hal ini sejalan dengan pendapat sudjana dalam aprinawati (2009: 22-23) "bahwa dalam proses belajar mengajar, hasil belajar yang diharapkan dapat dicapai peserta didik pentig diketahui oleh guru, agar guru dapat merancang/mendesain pengajaran secara tepat dan penu arti”.
Berdasarkan data terdapat permasalahan dalam keterampilan proses sains peserta didik di SDN 005 Langgini. ditemukan permasalahan dalam pembelajaran ilmu pengetahuan alam di kelas IV. diketahui dalam proses keterampilan sains yang melibatkan kegiatan percobaan pembelajaran,

1) Terlihat dalam kegiatan pembelajaran peserta didik kurang terampil dalam mengajukan pertanyaan yang berkaitan dengan materi yang telah dijelaskan oleh guru.

2) Peserta didik kurang aktif dalam bekerja sama dalam kelompok yang telah ditentukan oleh guru.

3) Peserta didik kurang terampil dalam mengumpulkan informasi

4) Peserta didik kurang mengembangkan kemampuan berfikirnya terhadap materi yang telah dipelajari

5) Peserta didik kurang terampil dalam menyimpulkan percobaan/observasi yang telah dilakukan pada saat proses pembelajaran yang dilakukan dalam kelompok, dan peserta didik hanya menerima informasi dari guru dalam menemukan dan menghubungkan suatu konsep dalam pembelajaran.

Sesuai data dan informasi yang penulis dapatkan dari guru yang bersangkutan. permasalahan tersebut, perlu adanya suatu formasi yang membuat peserta didik lebih mengoptimalkan cara berpikir untuk mengembangkan ide-ide peserta didik, karena pembelajaran IPA diharapkan dapat menjadi tempat bagi peserta didik untuk mempelajari diri sendiri dan alam sekitar, serta prospek pengembangan lebih lanjut dalam menerapkannya dalam kehidupan sehari-hari.

Berdasarkan data bahwa keterampilan proses sains peserta didik kelas IV SD Negeri 005 Langgini pada tahun ajaran 2017/2018 masih terdapat peserta didik yang tidak tuntas. Dalam hal ini tentunya terjadi masalah pada keterampilan proses sains peserta didik karena tidak sesuai dengan hasil yang di harapkan. Ketuntasan Minimum (KKM) yaitu, 75. Hal tersebut terlihat pada rekapitulasi nilai peserta didik seperti yang dibawah ini: 
Rekaputulasi Keterampilan Proses Sains Peserta didik Kelas IV

\begin{tabular}{|c|c|c|c|}
\hline Kelas & Jumlah siswa & Tuntas & Tidak Tuntas \\
\hline IV A & 28 & 12 & 16 \\
\hline IV B & 24 & 10 & 14 \\
\hline IV C & 25 & 11 & 14 \\
\hline
\end{tabular}

Sumber: Guru Kelas IV SDN 005 Langgini

Berdasarkan permasalahan yang terjadi pada peserta didik kelas IV SDN 005 Langgini upaya untuk mencapai pembelajaran yang diharapkan dapat mengembangkan keterampilan proses sains peserta didik adalah pembelajaran berbasis paradigma konstruktivistik. Menurut pandangan konstruktivistik, satu prinsip yang paling penting dalam psikologi pendidikan adalah bahwa guru tidak hanya sekedar memberikan pengetahuan kepada peserta didik. peserta didiklah yang harus membangun sendiri pengetahuannya, Trianto dalam fadilah (2007: 13).

Salah satu pembelajaran yang berpaham konstruktivistik adalah pembelajaran dengan menggunakan model Cycle Learning 5E, sesuai dengan teori belajar piaget, teori belajar berbasis konstruktivisme. Menurut Shoimin (2016 :58) Cycle Learning 5E (Pembelajaran bersiklus) adalah suatu model pembelajaran yang berpusat pada peserta didik. Prinsipnya mengarahkan peserta didik dalam menemukan suatu konsep. Dalam penerapannya model Cycle Learning, peserta didik akan ditugaskan untuk melakukan kegaiatan pengamatan secara berkelompok dan menggunakan alat serta bahan yang telah diberikan. Dengan instruksi yang telah diberikan dalam lembar kerja. Peserta didik akan membuat laporan hasil pengamatan serta mempresentasikan haasil pengamatan kepada peserta didik lainnya. Kegiatan tersebut akan dapat mengoptimalkan keterampilan proses sains. Menurut Lorsbach dalam Anisa (2009: 171-172) Penerapan model Cycle $5 E$ terdiri dari 5 tahap yaitu tahap engagement (pembangkit minat), tahap exploration (penyelidikan), tahap explanation (penjelasan), tahap elaboration (penggalian) dan tahap evaluation (penilaian).
Berdasarkan pendapat ahli tersebut, dapat peneliti simpulkan bahwa dalam penerapan model pembelajaran Cycle Learning $5 E$ peserta didik yang berperan aktif, terampil menemukan sendiri konsep dan melakukan percobaan dan peserta didik dapat meningkatkan pemahaman dan prestasi belajar dan juga membantu peserta didik menikmati sains, mengerti materi, dan mengaplikasikannya dalam situasi ilmiah..

Berdasarkan latar belakang yang telah dikemukakan di atas, maka penulis akan melakukan penelitian dengan menerapkan model pembelajaran Cycle Learning 5E dalam penelitian kuasi eksperimen dengan judul "Pengaruh Model Pembelajaran Cycle Learning 5E Terhadap Keterampilan Proses Sains Peserta Didik Kelas IV SDN 005 Langgini ".

Berdasarkan latar belakang yang telah dikemukakan, maka rumusan masalah dalam penelitian ini adalah "Seberapa besar pengaruh model pembelajaran Cycle Learning 5E yang diterapkan pada kelas eksperimen dibanding kelas kontrol yang menerapkan model $P O E$ terhadap Keterampilan Proses Sains pada peserta didik kelas IV SDN 005 Langgini ?"

\section{METODOLOGI PENELITIAN}

Metode yang digunakan dalam penelitian ini adalah quasi eksperimen Sugiyono (2012: 114) menjelaskan "bahwa desain quasi eksperimen mempunyai kelompok kontrol, tetapi tidak dapat berfungsi sepenuhnya untuk mengontrol variabelvariabel luar yang mempengaruhi pelaksanaan eksperimen". Desain quasi eksperimen yang digunakan dalam penelitian ini adalah Pretest Posttest Design dalam desain ini terdapat dua kelompok yang 
dipilih secara random, kemudian kelompok eksperimen diberikan perlakuan pembelajaran IPA dengan model pembelajaran Cycle Learning 5E, sedangkan kelompok kontrol dengan model pembelajaran $P O E$.

Apabila digambarkan, desain penelitian yang digunakan adalah eksperimen semu yang dapat diilustrasikan dalam tabel 3.1 berikut ini:

Tabel 3.1

Pretest-Posttest-Design

\begin{tabular}{|c|l|l|l|}
\hline Grup & Pretest & Perlakuan & Posttest \\
\hline
\end{tabular}

Populasi yang diambil dalam penelitian ini adalah semua peserta didik kelas IV SDN 005 Langgini. Menurut Sugiyono (2016: 113) menjelaskan "bahwa populasi merupakan wilayah generalisasi yang terdiri atas obyek/subyek yang mempunyai kualitas dan karakteristik tertentu yang ditetapkan oleh peneliti untuk dipelajari dan kemudian ditarik kesimpulannya". Dengan demikian dapat disimpulkan populasi dalam penelitian ini adalah peserta didik kelas IV SD Negeri 005 Langgini Bangkinang yang berjumlah 77 peserta didik yang terdiri dari kelas IV A, kelas IV B, dan kelas IV C. Ketiga kelas diambil dua kelas untuk dijadikan sebagai sampel dalam penelitian.

Menurut Sugiyono (2016: 114) sampel merupakan bagian dari jumlah dan karakteristik yang dimiliki oleh populasi tersebut. Sampel dalam penelitian ini kelas IV SD 005 Langgini Bangkinang yang terbagi dari dua kelompok eksperimen dan kelompok kontrol.

Teknik pengambilan sampel yang digunakan dalam penelitian ini adalah dengan cara purposive sampling yaitu teknik pengambilan sampel sumber data dengan pertimbangan tertentu, misalnya orang tersebut dianggap paling tahu tentang apa yang kita harapkan (sugiyono, 2012). Berdasarkan usulan dari guru dan kepala sekolah maka dipilihkan kelas IV B sebagai kelas eksperimen yang berjumlah 24 peserta didik dengan menerapkan model pembelajaran Cycle Learning $5 E$ sedangkan kelas IV C yang berjumlah 25 peserta didik sebagai kelas kontrol dengan menerapkan model pembelajaran $P O E$.

Teknik-teknik pengumpulan data yang digunakan dalam penelitian ini adalah sebagai berikut:

\begin{tabular}{|c|c|c|c|}
\hline Eksperimen & $\mathrm{O}_{1}$ & $\mathrm{X}_{1}$ & $\mathrm{O}_{2}$ \\
\cline { 2 - 4 } (Subro19tiglyon & $0,2034)$ & - & $\mathrm{O}^{4}$ \\
\hline
\end{tabular}

Keterangan:

$\mathrm{X}_{1}=$ Perlakuan pada kelas eksperimen

- = Perlakuan pada kelas kontrol

$\mathrm{O}_{1}=$ Pretes kelas eksperimen

$\mathrm{O}_{2}=$ Postes kelas eksperimen

$\mathrm{O}_{3}=$ Pretes kelas kontrol $\mathrm{O}_{4}$

$=$ Postes kelas kontrol

\section{Observasi}

Menurut Sugiyono (2016: 145) menjelaskan "bahwa observasi merupakan suatu proses yang kompleks, suatu proses yang tersusun dari perbagai proses biologis dan psikologis". Dua diantara yang terpenting adalah proses-proses pengamatan dan ingatan. Observasi ini dilakukan untuk memperoleh informasi pelaksanaan pembelajaran dengan bantuan lembar observasi keterlaksanaan pembelajaran terhadap model pembelajaran Cycle Learning 5e dan model pembelajaran $P O E$,

\section{Dokumentasi}

Menurut Sugiyono (2016: 240) menjelaskan bahwa dokumen merupakan catatan peristiwa yang sudah berlalu. Dokumen bisa berbentuk tulisan, gambar, atau karya-karya monumental dari seseorang. Dokumentasi yang diperlukan dalam penelitian ini adalah data nama peserta didik dan hal-hal yang berkaitan dengan kebutuhan dalam penelitian. Teknik dokumentasi lainnya yaitu menggunakan bantuan kamera untuk mendokumentasikan proses kegiatan pembelajaran.

\section{Wawancara}

Menurut Kunandar (2011:157) wawancara merupakan pertanyaanpertanyaan yang diajukan secara verbal kepada orang-orang yang diangap dapat memberikan informasi atau penjelasan halhal yang dianggap perlu dalam permasalahan penelitian. Wawancara digunakan untuk memperoleh data mengenai 
pendapat guru terhadap kegiatan pembelajaran yang selama ini berlangsung.

Selain teknik yang digunakan dalam mengumpulkan data digunakan juga instrument dalam pengumpulan data. Adapaun instrument yang digunakan dalam pengumpulan data yaitu sebagai berikut:

1. Lembar Observasi Aktifitas guru

Berisi pengamatan terhadap kegiatan guru selama pelaksanaan pembelajaran berlangsung.

2. Lembar Observasi Keterampilan Proses Sains

Berisi pengamatan terhadap aspek keterampilan proses sains yaitu keterampilanmengobservasi, kuantifikasi, klasifikasi, prediksi, mengkomunikasikan dan inferensi.

3. Tes

Tes merupakan salah satu alat pengumpulan data yang terdiri dari pertanyaan-pertanyaan atau latihan yang digunakan untuk mengukur kemampuan, pengetahuan atau minat dan bakat yang dimiliki oleh seseorang atau kelompok. Dalam penelitian ini peneliti menggunakan tes berupa soal uraian untuk mengukur keterampilan proses sains siswa.

\section{HASIL PENELITIAN DAN PEMBAHASAN}

Berdasarkan hasil penelitian yang sudah didapatkan. Maka ada beberapa hal yang perlu dibahas terkait penelitian ini, yaitu kelebihan dan kelemahan penerapan model pembelajaran cycle learning 5E dalam proses pembelajaran untuk meningkatakan keterampilan proses sains peserta didik. Model ini terdiri dari 5 tahapan, yaitu : (1) pembangkitan minat (engagement), (2) eksplorasi (exploration), (3) penjelasan (explanation), (4) elaborasi (elaboration), (5) evaluasi (evaluation).

Pada proses penelitian yang dilakukan peneliti untuk meningkatkan keterampilan proses sains dengan menggunakan model cycle learning $5 \mathrm{E}$ ditemukan kelebihan model cycle learning 5E saat pembelajaran yaitu peserta didik dapat menemukan pengalaman langsung, peserta didik bekerja sama

$$
\text { Zainal Arifin }
$$

menjelaskan bahwa tes uraian menuntut peserta didik untuk menguraikan, mengorganisasikan dan menyatakan jawaban dengan kata-katanya sendiri dalam bentuk, teknik, dan gaya yang berbeda satu dengan yang lainnya. Dengan demikian maka dalam tes uraian akan menuntut peserta didik untuk lebih berpikir secara kritis dalam menjawab soal-soal yang diajukan, selain itu, tes uraian ini juga membuat peserta didik menjadi lebih berpusat pada kegiatan menganalisis.

$\quad \begin{aligned} & \text { Adapun indikator } 6 \\ & \text { keterampilan } 6 \text { indikator } \\ & \text { mengamati, kuantifikasi, klasifikasi, }\end{aligned}$
prediksi, komunikasi, inferensi.

Analisis dan interpretasi data dengan menggunakan prasyarat analisis dan uji hipotesis.

Uji normalitas dianalisis dengan KolmogorovSmirnov dan uji homogenitas dianalisis dengan uji Levence. Hipotesis di analisis dengan menggunakan Analyze-Compare Means-Oneway Anova. Keseluruhan analisis data dilakukan dengan menggunakan SPSS $v$-20.

dalam kelompok dan peserta didik dapat mengembangkan kemampuan yang dimiliki karena peserta didik terlibat langsung, aktif dalam pemecahan masalah. Kelebihan model cycle learning 5E menurut menurut Shoimin (2016: 60), yaitu Meningkatkan motivasi belajar karena pembelajaran di libatkan secara aktif dalam proses pembelajaran, Peserta didik dapat menerima pengalaman dan di mengerti oleh orang lain, Peserta didik mampu mengembangkan potensi individu yang berhasil dan berguna, kreatif ,bertanggung dan mengoptimalkan dirinya terhadap perubahan yang terjadi dan Pembelajaran lebih bermakna. Sejalan dengan shoimin dan Ngalimun dalam Budianti (2010: 150), yaitu: cycle learning 5E Meningkatkan motivasi belajar karena pembelajaran dilibatkan secara aktif dalam proses pembelajaran, Membantu mengembangkan sikap ilmiah pebelajar dan Membelajar lebih bermakna.

Berdasarkan data awal dan data akhir kelas ekpserimen yang telah dilaksanakan maka diketahui 
nilai rata-rata awal pada kelas eksperimen sebesar 58,75 dan nilai rata-rata data akhir dari keterampilan proses sains peserta didik yang diajarkan dengan model cycle learning 5E sebesar 81,25 . Ini menunjukkan adanya peningkatan yang signifikan dari rata-rata yang telah diperoleh kelas ekpserimen.

Berdasarkan uji persyaratan analisis data diperoleh bahwa kelas eksperimen dan kelas kontrol berdistribusi normal dan homogen, maka uji hipotesis yang dilakukan dalam penelitian ini menggunakan uji-t pada taraf signifikan 0,05.

Pengujian hipotesis pada penelitian ini menggunakan data posttest peserta didik dengan menggunakan perhitungan nilai rata-rata dan nilai standar deviasi pada kelas kontrol dan kelas eksperimen. Berdasarkan perhitungan SPSS, maka diperoleh hasil thitung $=2,877$ dengan $\mathrm{df}=23$ pada taraf signifikan $=0,05$ maka dari tabel distribusi $t$

di peroleh nilai $t_{(0,05)(23)}=1,714$. Karena $h \quad>$ yaitu $2,877>1,714$ dengan demikian

diterima dan o ditolak sehingga dapat disimpulkan bahwa adanya pengaruh model pembelajaran Cycle Learning $5 E$ terhadap keterampilan proses sains peserta didik di SD Negeri 005 Langgini.

\section{SIMPULAN}

Berdasarkan hasil penelitian yang telah dilakukan dan disesuaikan dengan pembahasan

\section{DAFTAR PUSTAKA}

Anisa, R. N. (2018). Pengaruh Model Learning Cycle Terhadap Keterampilan Proses Sains Siswa Pada Mata Pelajaran IPA Kelas III SD Negeri Harja Mekar 03 Kec. Cikarang Utara. Jurnal Bidang Pendidikan Dasar, 2(1A), 12-22.

Aprinawati, i. Peningkatan hasil belajar ipa dengan model pembelajaran problem based instruction pada kelas $\mathrm{v}$ sd. Js (jurnal sekolah), 1(2), 33-42.

Budianti, Y., \& Safiyyah, I. (2017). Upaya Meningkatkan Keterampilan Proses melalui Model Siklus Belajar (Learning Cycle) pada Pembelajaran Ilmu Pengetahuan Alam Siswa Kelas IV SD Negeri Wanasari 14 Bekasi. PEDAGOGIK

(JURNAL yang telah dijabarkan tentang model pembelajaran Cycle Learning 5E dalam meningkatkan keterampilan proses sains peserta didik kelas IV SDN 005 Langgini yang bertujuan untuk mengetahui pengaruh terhadap keterampilan proses sains pembelajaran tematik tema 1 pembelajaran Terdapat perbedaan yang signifikan terhadap keterampilan proses sains siswa pembelajaran tematik tema 1 pembelajaran IPA antara peserta didik yang belajar melalui model cycle learning $5 \mathrm{E}$ dengan peserta didik yang belajar melalui model pembelajaran $P O E$. Hal ini dapat dilihat dari nilai rata-rata skor dengan hasil analisis uji-t dua diperoleh skor rata-rata posttest kelas eksperimen $81,25 \%$ lebih tinggi dari skor rata-rata posttest pada kelas kontrol 74,4\%. Hasil uji statistik menunjukkan bahwa thitung 2,877 > ttabel 1,714 untuk taraf signifikan $95 \%$ dan $\alpha=$ 0,05 sehingga diterima dan 0 ditolak. Hal ini menunjukkan bahwa penggunaan model pembelajaran Cycle Learning 5E berpengaruh

PENDIDIKAN SEKOLAH DASAR), 5(I), $72-82$

Depdiknas .2003. Undang-undang RI No.20 tahun 2003.tentang sistem pendidikan nasional.

Fadhilah, n., \& ayu, n. R. Pengaruh pendekatan pembelajaran predict-observe-explain terhadap kemampuan berpikir kreatif siswa smp kelas vii yayasan pendidikan islam.

Kurino, y. d. (2018, december). upaya meningkatkan hasil belajar siswa melalui model predict observe explain (poe) pada mata pelajaran matematika. in sepeda (seminar pendidikan dasar) pgsd fkip unpas (vol. 1, no. 1, pp. 2028). 
Shoimin, Aris, (2016) 68 Model Inovatif Dalam Kurikulum 2013, Yogyakarta: AR-RUZZ MEDIA, 2016

Sugiyono. (2014). Metode Penelitian Kuantitatif Kualitatif dan $R \& D$. Bandung: Alfabeta.

Zainal Arifin. (2009). Evaluasi Pembelajaran.

Bandung: Remaja Rosdakarya. 